\title{
Hubungan perasaan takut anak terhadap perawatan gigi dengan kebersihan gigi dan mulut di RSGM Unsrat Manado
}

\author{
${ }^{1}$ Chinda B. Bunga'Allo \\ ${ }^{2}$ Benecditus S. Lampus \\ ${ }^{3}$ Paulina N. Gunawan
}

\author{
${ }^{1}$ Kandidat Skripsi Program Studi Pendidikan Dokter Gigi Fakultas Kedokteran \\ ${ }^{2}$ Bagian Ilmu Kesehatan Masyarakat Fakultas Kedokteran \\ ${ }^{3}$ Program Studi Pendidikan Dokter Gigi Fakultas Kedokteran \\ Universitas Sam Ratulangi Manado \\ Email: beatrizbunga28@ rocketmail.com
}

\begin{abstract}
Child fear often becomes a barrier for dentists to provide optimal care. Therefore, it is important for the dentists to establish good relationship with patients, especially children. Children who have positive interaction with the dentists can handle their fears and will not be afraid to the dentists, so they are expected to have good oral hygiene. This study was aimed to analyze the relationship beetween children's feeling of fear against dental treatment and their oral hygiene at Dental Hospital University of Sam Ratulangi. Samples were children aged 6-12 who had received dental treatment before. This was a descriptive analytical study with a cross sectional design. Data were obtained by using questionnaires and examination of OHIS. The results showed that of the 35 respondents, 23 children $(65.7 \%)$ were not afraid of dental treatment $(65,7 \%)$, meanwhile 12 children $(34.3 \%)$ were afraid of dental treatment. There were 28 children $(80 \%)$ that preferred female dentists to male dentists menawhile 7 children (20\%) were the opposites. There were 23 children $(65.7 \%)$ that liked dentists who used self protective equipment and 12 children (34.3\%) did not. There were 21 children $(60 \%)$ that had good OHI-S and 14 children (40\%) that had moderate OHI-S. The Fisher alternative test showed a sinificancy of 1.000 for 2-sided (two tail) and 0.583 for 1-sided (one tail) ( $p>0.05$ ) Conclusion: There was no relationship between children's feelings of fear against dental treatment and oral hygiene.
\end{abstract}

Keywords: feelings of fear, dental treatment, oral hygiene

\begin{abstract}
Abstrak: Perasaan takut dan cemas pada anak sering menjadi penghalang bagi dokter gigi untuk memberikan perawatan yang optimal. Oleh karena itu, dokter gigi perlu menjalin hubungan baik dengan pasien khususnya pasien anak. Anak yang memiliki interaksi positif terhdap dokter gigi dapat mengatasi rasa takutnya sehingga mereka tidak akan takut ke dokter gigi dan memiliki kesehatan gigi dan mulut yang baik. Penelitian ini bertujuan untuk menganalisis hubungan antara rasa takut pada anak terhadap perawatan gigi dengan kebersihan gigi dan mulut di RSGM Unsrat. Sampel penelitian ialah anak berusia 6-12 tahun yang sudah pernah menerima perawatan gigi sebelumnya. Jenis penelitian ialah deskriptif analitik dengan desain potong lintang. Pengumpulan data menggunakan pengisian kuesioner dan pemeriksaan OHIS. Hasil penelitian menunjukkan dari 35 responden, yang tidak takut terhadap perawatan gigi 23 anak $(65,7 \%)$ dan yang takut terhadap perawatan gigi 12 anak (34,3\%). Yang memilih dirawat oleh dokter gigi perempuan 28 anak (80\%) sedangkan yang memilih dirawat dokter gigi laki-laki 7 anak (20\%). Yang menyukai dokter gigi menggunakan pelindung diri sebanyak 23 anak $(65,7 \%)$ dan yang tidak menggunakan pelindung diri 12 anak (34,3\%). Yang memiliki OHI-S baik 21 anak (60\%) dan yang memiliki OHI-S sedang 14 anak (40\%). Hasil uji alternatif Fisher mendapatkan nilai signifikansi 1,000 untuk 2-sided (two tail) dan 0,583 untuk 1-sided (one tail) ( $\mathrm{p}>0,05)$ Simpulan: Tidak terdapat hubungan antara rasa takut anak terhadap perawatan gigi dengan kebersihan gigi dan mulut.
\end{abstract}

Kata kunci: perasaan takut, perawatan gigi, kebersihan gigi dan mulut 
Masalah kesehatan gigi dan mulut merupakan salah satu masalah yang dapat mengganggu aktivitas sehari-hari. Pada anak-anak, gangguan tersebut akan mengurangi aktivitas, frekuensi kehadiran di sekolah, mengganggu konsentrasi belajar, serta memengaruhi nafsu makan dan asupan gizi. ${ }^{1}$

Untuk mengatasi masalah kesehatan gigi dan mulut yang dialami oleh anak, orang tua mengajak anak berobat ke dokter gigi namun dalam prakteknya, kebanyakan anak-anak kurang kooperatif selama proses perawatan sehingga dokter gigi mengalami kesulitan menangani anak. Kesulitan untuk menangani anak tidak hanya berhubungan dengan proses perawatan, tetapi juga perbedaan emosional. Rasa gelisah dan takut merupakan emosi yang paling sering ditunjukkan oleh anak selama perawatan di dokter gigi. $^{2}$

Perasaan takut terhadap perawatan gigi merupakan hambatan bagi dokter gigi dalam usaha peningkatan kesehatan gigi masyarakat. Umumnya perasaan takut timbul akibat pengalaman perawatan gigi semasa kanak-kanak; oleh karena itu perlu diperhatikan bahwa pencegahan timbulnya perasaan takut harus dimulai pada usia dini. ${ }^{3}$ Perasaan takut yang dialami anak merupa-kan naluri yang timbul sesuai proses perkembangan. Perasaan ini timbul melalui pengamatan terhadap objek yang tidak menyenangkan dan secara naluri dihindari dalam usaha melindungi diri dari bahaya. Hal ini sering menjadi alasan untuk mengabaikan perawatan gigi. ${ }^{4}$

Prevalensi kecemasan dental di seluruh dunia mencapai 6-15\% dari seluruh populasi, tetapi cukup bervariasi di berbagai negara dan pada populasi sampel yang berbeda. ${ }^{4}$ Berdasarkan survei oleh Al Sarheed, 5-6\% populasi dan $16 \%$ dari anak usia sekolah memiliki perasaan takut ke dokter gigi., Hasil penelitian di Indonesia ditemukan sebanyak $22 \%$ menyatakan rasa takut dan cemas terhadap perawatan gigi. ${ }^{6}$

Perasaan takut terhadap perawatan gigi dapat dijumpai pada anak-anak diberbagai unit pelayanan kesehatan gigi misalnya di praktek dokter gigi, di rumah sakit maupun puskesmas. $^{7}$ Menurut studi yang dilakukan oleh Kartono dan Sartono pada tahun 1992 di Sutadi, terdapat 3 faktor yang memengaruhi kecemasan yaitu: suara dari bur $81,46 \%$, duduk di dental chair 50,72\%, jarum $39,13 \%$, dental instrument $39,13 \%$ dan cerita pengalaman negatif tentang perawatan gigi dari orang lain $33,33 \% .^{8}$

Perasaan takut dan kecemasan yang dialami anak selama perawatan gigi bukan fenomena baru dalam bidang kedokteran gigi. Rasa takut anak sering menjadi penghalang bagi dokter gigi untuk memberikan perawatan yang optimal. Oleh karena itu penting bagi dokter gigi menjalin hubungan yang baik dengan pasien khususnya pasien anak. Anak yang memiliki interaksi positif terhdap dokter gigi dapat mengatasi rasa takutnya sehingga mereka tidak akan takut ke dokter gigi dan memiliki kesehatan gigi dan mulut yang baik.

RSGM Unsrat merupakan salah satu pusat perawatan gigi dan mulut di Kota Manado dengan pasien yang berkunjung pun beragam dari berbagai golongan, mulai masyarakat ekonomi menengah bawah sampai ekonomi menengah atas. Penelitian ini bertujuan untuk mengetahui hubungan antara perasaan takut anak terhadap perawatan gigi dengan kebersihan gigi dan mulut di RSGM Unsrat.

\section{BAHAN DAN METODE PENELITIAN}

Jenis penelitian ini ialah deskriptif analitik dengan desain potong lintang. Penelitian ini dilaksanakan di RSGM Unsrat pada bulan Juni 2016. Sampel berjumlah 35 anak yang diperoleh dengan metode total sampling.

Perasaan takut anak ialah perasaan yang dialami anak selama proses perawatan gigi yang dilakukan oleh dokter gigi muda (coass) di RSGM Unsrat. Perawatan yang diterima meliputi pencabutan gigi, penambalan gigi, pembersihan karang gigi, pengobatan gigi, dan perawatan gigi lainnya. Data perasaan takut anak terhadap perawatan gigi diukur melalui jawaban kuesioner dengan menggunakan skala Guttman. Terdapat 7 pertanyaan dengan 
jawaban ya atau tidak. Tidak takut, jika responden menjawab semua pertanyaan dengan jawaban tidak; dan takut, jika responden menjawab salah satu atau beberapa pertanyaan dengan jawaban ya.

Kebersihan gigi dan mulut anak diukur dengan menjumlahkan skor indeks debris dan indeks kalkulus. Indeks Oral Hygiene Simplified (OHI-S) merupakan penjumlahan dari indeks debris dan indeks kalkulus dengan kriteria baik bila nilai OHIS antara $0-1,2$; sedang, bila nilai OHIS 1,3-3; dan buruk, bila nilai OHIS 3,1-6.

Setelah melengkapi informed consent, dilakukan tanya jawab untuk mengisi lembar kuisioner. Kebersihan gigi dan mulut anak diperiksa menggunakan sonde dan kaca mulut lalu dicatat hasilnya dalam lembar pemeriksaan OHIS. Data diolah menggunakan SPSS dan dianalisis secara univariat disajikan dalam bentuk tabel dan secara bivariat menggunakan uji alternatif Chi-square, yaitu uji Fisher.

\section{HASIL PENELITIAN}

Berdasarkan hasil penelitian diperoleh sampel sebanyak 35 anak. Karateristik anak dibedakan atas jenis kelamin dan usia. Untuk jenis kelamin, ditemukan jumlah anak perempuan lebih dominan yaitu sebanyak 24 orang $(68,6 \%)$ dibandingkan laki-laki sebanyak 11 orang $(31,4 \%)$. Untuk kelompok usia 6-12 tahun, usia 7 tahun paling banyak yaitu 15 orang $(42,9 \%)$ sedangkan usia 12 tahun tidak ada.

Tabel 1 menunjukkan bahwa dari 35 anak, persentase terbesar menyatakan tidak takut terhadap perawatan gigi yaitu sebanyak 65,7\% (32 anak).

Tabel 1. Distribusi perasaan takut anak terhadap perawatan gigi

\begin{tabular}{ccc}
\hline Perasaan & Jumlah $(\mathrm{n})$ & $(\%)$ \\
\hline Tidak takut & 23 & 65,7 \\
Takut & 12 & 34,3 \\
Total & 35 & 100 \\
\hline
\end{tabular}

Tabel 2 menunjukkan bahwa dari 35 anak, semua dalam kategori sedang (40\%) sampai baik (60\%) dan tidak ada anak yang memiliki OHI-S buruk.
Tabel 2. Distribusi kebersihan gigi dan mulut anak

\begin{tabular}{ccc}
\hline OHI-S & Jumlah (n) & $\%$ \\
\hline Baik & 21 & 60 \\
Sedang & 14 & 40 \\
Buruk & 0 & 0 \\
Total & 35 & 100 \\
\hline
\end{tabular}

Tabel 3 menunjukkan bahwa persentase terbesar berjumlah 14 anak (40\%) tidak takut terhadap perawatan gigi serta memiliki OHI$\mathrm{S}$ baik, sedangkan persentase terkecil berjumlah 5 anak $(14,3 \%)$ takut terhadap perawatan gigi dan memiliki OHI-S sedang.

Hasil uji alternatif Fisher diperoleh nilai signifikansi 1,000 untuk 2-sided (two tail) dan 0,583 untuk 1-sided (one tail) ( $\mathrm{p}$ $>0,05$ ) yang menunjukkkan tidak terdapat hubungan antara perasaan takut anak terhadap perawatan gigi dengan kebersihan gigi dan mulut.

Tabel 3. Hubungan perasaan takut anak terhadap perawatan gigi dengan kebersihan gigi dan mulut anak

\begin{tabular}{ccccccc}
\hline OHI-S & \multicolumn{3}{c}{ Perasan anak } & \multicolumn{2}{c}{ Total } \\
& \multicolumn{2}{c}{ Tidak takut } & \multicolumn{2}{c}{ Takut } & & \\
\cline { 2 - 5 } & $\mathrm{n}$ & $\%$ & $\mathrm{n}$ & $\%$ & $\mathrm{n}$ & $\%$ \\
\hline Baik & 14 & 40 & 7 & 20 & 21 & 60 \\
Sedang & 9 & 25,7 & 5 & 14,3 & 14 & 40 \\
Total & 23 & 65,7 & 12 & 34,3 & 35 & 100 \\
\hline Keterangan: $\mathrm{n}=$ jumlah & & & &
\end{tabular}

Berdasarkan hasil jawaban mengenai persepsi anak terhadap dokter gigi, persepsi anak dibagi dalam dua kategori yaitu dokter gigi yang merawat dan penampilan dokter gigi. Tabel 4 menunjukkan bahwa lebih banyak anak yang memilih dirawat oleh dokter gigi perempuan, yaitu sebesar 28 anak (80\%).

Tabel 4. Distribusi persepsi anak terhadap dokter gigi yang merawat

\begin{tabular}{lcc}
\hline Memilih dirawat & Jumlah $(\mathrm{n})$ & $(\%)$ \\
\hline $\begin{array}{l}\text { Dokter gigi } \\
\text { perempuan }\end{array}$ & 28 & 80 \\
$\begin{array}{l}\text { Dokter gigi laki- } \\
\text { laki }\end{array}$ & 7 & 20 \\
Total & 35 & 100 \\
\hline
\end{tabular}

Tabel 5 menunjukkan sekitar 23 anak 
$(65,7 \%)$ lebih menyukai dokter gigi yang menggunakan pelindung diri (masker dan sarung tangan).

Tabel 5. Distribusi persepsi anak terhadap penampilan dokter gigi

\begin{tabular}{lcc}
\hline \multicolumn{1}{c}{ Dokter gigi } & $\begin{array}{c}\text { Jumlah } \\
(\mathrm{n})\end{array}$ & $(\%)$ \\
\hline $\begin{array}{l}\text { Memakai pelindung diri } \\
\text { Tidak memakai }\end{array}$ & 23 & 65,7 \\
$\begin{array}{l}\text { pelindung diri } \\
\text { Total }\end{array}$ & 12 & 34,3 \\
\hline
\end{tabular}

\section{BAHASAN}

Pasien anak yang berkunjung ke RSGM Unsrat pada saat penelitian didominasi pasien berusia 7 tahun sebanyak 15 anak (42,9\%). Dari 12 anak yang takut terhadap perawatan gigi, yang berusia 6 tahun 2 anak, berusia 7 tahun 7 anak, dan berusia 8 tahun 3 anak. Usia dapat memengaruhi perasaan takut; anak yang usianya jauh lebih tua akan lebih bisa mengendalikan diri, bertanggung jawab, patuh, dan dapat menunjukkan keberanian. ${ }^{9}$

Hasil penelitian mendapatkan dari 35 anak yang tidak takut terhadap perawatan gigi sebanyak 23 anak $(65,7 \%)$ sedangkan yang takut dengan perawatan gigi sebanyak 12 anak (34,3\%). Berdasarkan pengamatan peneliti, beberapa anak merupakan pasien yang diajak langsung oleh operator (co-ass) untuk berobat ke RSGM. Tipe pasien anak yang dibawa oleh operator yaitu keluarga operator, kerabat operator, dan anak di panti asuhan yang dijemput untuk dibawa dan dirawat ke RSGM. Sebelum dibawa ke RSGM, sudah terjadi interaksi awal antara operator dan pasien sehingga telah terjalin keakraban dan kepercayaan pasien kepada operator. Hal ini tentunya sangat memengaruhi kesiapan anak-anak untuk memeriksakan giginya ke RSGM dan memengaruhi perasaan anak sehingga anak lebih siap dan dapat mengendalikan perasaan takutnya.

Pengalaman buruk pada perawatan gigi sebelumnya dapat menjadi penyebab rasa takut anak yang sudah pernah datang ke RSGM dan mendapatkan perawatan. Pada penelitian ini terdapat 12 anak $(34,3 \%)$ yang takut terhadap perawatan gigi. Jenis perawatan yang membuat anak takut terhadap perawatan gigi ada berbagai macam; 6 anak takut terhadap suntikan, 6 anak takut terhadap bur gigi; 4 anak takut terhadap pencabutan gigi; dan 1 anak takut terhadap tambalan gigi.

Hasil pemeriksaan kebersihan gigi dan mulut menggunakan OHI-S mendapatkan 21 anak (60\%) yang memiliki OHI-S baik dan 14 anak (40\%) memiliki OHI-S sedang; tidak ada anak yang memiliki OHI$\mathrm{S}$ buruk. Anak yang rutin mengunjungi dokter gigi lebih paham tentang cara menjaga kebersihan gigi dan mulutnya. Penelitian yang dilakukan oleh Adeputri ${ }^{7}$ di Medan pada dua sekolah berbeda yaitu SDN 060919 yang tidak memiliki fasilitas klinik gigi dan SD Islam Namira yang memiliki fasilitas kinik gigi. Rata-rata indeks oral hygiene pada siswa SD Islam Namira lebih rendah dari SDN 060919. Anak yang sering mengunjungi klinik gigi memiiki status kebersihan gigi mulut yang baik dibandingkan anak yang jarang mengunjungi klinik gigi.

Berdasarkan persepsi anak terhadap dokter gigi yang merawat, 28 anak $(80 \%)$ memilih dirawat oleh dokter gigi perempuan dan 7 anak (20\%) memilih dirawat oleh dokter gigi laki-laki. Terdapat 23 anak $(65,7 \%)$ lebih menyukai dokter gigi yang memakai pelindung diri (masker, sarung tangan) dan 12 anak $(34,3 \%)$ menyukai dokter gigi yang tidak menggunakan pelindung diri.

Berdasarkan hasil penelitian dapat dilihat bahwa terdapat 14 anak (40\%) yang tidak takut terhadap perawatan gigi dan memiliki OHI-S baik; 9 anak $(25,7 \%)$ yang tidak takut terhadap perawatan gigi dan memiliki OHI-S sedang; 7 anak (20\%) yang takut terhadap perawatan gigi dan memiliki OHI-S baik; dan 5 anak $(14,3 \%)$ takut terhadap perawatan gigi dan memiliki OHI-S sedang. Hasil ini menunjukkan bahwa perasaan anak terhadap perawatan gigi tidak memengaruhi kebersihan gigi dan mulut. Meskipun anak tidak takut terhadap perawatan gigi, tetapi masih ada anak yang memiliki status kebersihan gigi dan mulut sedang dan anak yang takut 
terhadap perawatan gigi tetapi memiliki status kebersihan gigi dan mulut yang baik. Hasil uji korelasi Fisher test menunjukkan tidak terdapat hubungan antara perasaan takut anak terhadap perawatan gigi dengan kebersihan gigi dan mulut.

\section{SIMPULAN}

Dari hasil penelitian terhadap pasien anak di RSGM Unsrat Manado dapat disimpulkan bahwa tidak terdapat hubungan antara perasaan takut anak terhadap perawatan gigi dengan kebersihan gigi dan mulut.

\section{SARAN}

Diharapkan peran orang tua untuk membiasakan anak melakukan kunjungan berkala ke dokter gigi sejak dini minimal 6 bulan sekali, sehingga anak terbiasa dengan perawatan gigi dan dapat mengendalikan rasa takut terhadap dokter gigi.

Dokter gigi bersikap lebih ramah, memberi kesan menarik dan mengakrabkan diri dengan pasien anak agar terjalin rasa percaya dan mengurangi rasa takut pada anak.

\section{DAFTAR PUSTAKA}

1. Dumaha S. Gambaran prilaku ibu tentang kesehatan gigi dan mulut di perumahan Brimob Manado. Dentire Journal. 2012;1:92.

2. Mittal R, Sharma M. Assessment of psychological effects of dental treatment on children. Contemp Clin Dent. 2012;3(5):2-7.

3. Swastini IGAAP, Tedjasulaksana R, Nahak MM. Gambaran rasa takut terhadap perawatan gigi pada anak usia sekolah yang berobat ke puskesmas IV Denpasar Barat. Interdental. 2007;5:53.

4. Simon RA. Perbedaan tingkat kecemasan anak terhadap tindakan ekstraksi dan non ekstraksi di Bagian Kedokteran Gigi Anak, RSGMP Kandea [Skripsi]. Makassar: Fakultas Kedokteran Gigi Universitas Hasanuddin; 2014.

5. AlSarheed M. Children's perception of their dentists. Eur J Dent. 2011;5:186.

6. Andi SP. Pola prilaku anak terhadap perawatan gigi dan mulut [Skripsi]. Makassar: Fakultas Kedokteran Gigi Universitas Hasanuddin; 2014.

7. Adeputri MI. Rasa takut terhadap perawatan gigi dan satus kesehatan gigi anak pada SD Islam Manira dan SD 060919 [Skripsi]. Medan: Fakultas Kedoteran Gigi Universitas Sumatera Utara; 2011.

8. Setiawan AS, Zidnia H, Sasmita IS. Mozart effect on dental anxiety in 612 year old children. Dental Journal. 2010;43:18.

9. Leila A. Hubungan kecemasan pasien anak usia 6-13 tahun terhadap pencabutan gigi di Puskesmas Sumbersari Jember [Skripsi]. Jember: Fakultas Kedokteran Gigi Universitas Jember; 2015. 